\title{
The Effects of Institutional Difference and Resource Seeking Intent on Location Choice of Chinese Outward FDI
}

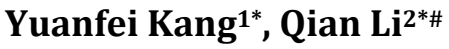 \\ ${ }^{1}$ Massey Business School, Massey University, Auckland, New Zealand \\ ${ }^{2}$ School of Economics and Management, Chang'an University, Xi'an, China \\ Email: Y.Kang@massey.ac.nz, "laplace0911@163.com
}

How to cite this paper: Kang, Y.F. and $\mathrm{Li}$, Q. (2018) The Effects of Institutional Difference and Resource Seeking Intent on Location Choice of Chinese Outward FDI. Theoretical Economics Letters, 8, 981-1003. https://doi.org/10.4236/tel.2018.85068

Received: December 29, 2017

Accepted: April 10, 2018

Published: April 13, 2018

Copyright $\odot 2018$ by authors and Scientific Research Publishing Inc. This work is licensed under the Creative Commons Attribution International License (CC BY 4.0).

http://creativecommons.org/licenses/by/4.0/ (c) (i) Open Access

\begin{abstract}
This study seeks to explain how differences in political risk and economic freedom between host and home countries interact with investing firms' resource-seeking intent to influence the firms' outward foreign direct investment (FDI) location choice. Using panel data covering Chinese outward FDI in 62 host countries during the period of 2003-2014, we performed panel data regression analysis. The results show that when firms' resource seeking intention is high, the FDI location choice is negatively associated with the differences in political risk, but positively associated with the differences in economic freedom between China and the host countries. The results also show that there is a substituting effect between political risk and economic freedom in their interactions with resource-seeking intent to influence FDI location choice. The findings suggest that the Chinese firms' outward FDI location choice is a result of the interplay and the fit between the firms' external legitimacy in the host countries and the firms' internal legitimacy within the multinational organization.
\end{abstract}

\section{Keywords}

FDI Location Choice, Resource Seeking Intent, Political Risk, Economic Freedom, Chinese Outward FDI

\section{Introduction}

Following the dramatic rise of emerging economies as a major source of outward foreign direct investment (FDI) in the world economy, institutional theory [1] [2] and strategic intent approach [3] have become increasingly important theo${ }^{*}$ Both authors contributed equally to the work. 
retical perspectives in explaining outward FDI strategies and behaviours of emerging economy multinational enterprises (EMNEs) [4] [5] [6] [7] [8]. FDI location choice strategy is one of the most significant topics underlying the pattern of internationalisation by EMNEs [9] [10]. Based on the institutional theory, considerable research attention has paid to how EMNEs made their locational decisions in responding to external institutional constrains in order to gain legitimacy in a foreign country [11] [12] [13] [14]. The strategic intent perspective draws attention to the factors internal to the firm and reveals how firms pursue and accomplish certain strategic intent through taking use of the locational advantages [15] [16]. Although insightful, it is insufficient to simply account for either firm's external forces or internal factors when addressing the firm's strategic choice such as FDI location choice. The way firms experience institutional demands is a function of the interplay between the firms' external and internal pressures [17], as firms often face an important trade-off between isomorphism and heterogeneity in their strategic decision in a given operating environment [18]. Thus, an integration of different theoretical perspectives in strategic management, especially in an emerging economy context becomes vital for a better understanding of the FDI behavioural patterns for EMNEs [19].

Firms' foreign direct investment decisions such as FDI location choice are under the influences of both the investing firms' external and internal institutional pressures, and this is particularly evident in the MNEs from emerging economy such as China [12] [20]. Maintaining foreign subsidiaries' internal legitimacy within the boundary of their multinational organization is critically important, as foreign subsidiaries may rely on internal support and critical resources from their parent firm when operating in foreign markets [21]. Due to the differences in the institutional systems between the home and host countries, the external demands in a host country can be significantly different from that of the firm, consequently creating conflicts between these two [5] [22]. Through exploring the interaction between a firm's external institutional pressures and internal strategic intent, this study advocates that an emerging economy firm may achieve both external legitimacy and internal legitimacy by carefully matching the institutional environment challenges in a prospective host country and the emerging country firm's specific ability in managing the challenges, and by matching out the economic development needs and interest of the host country and the strategic intent of the firm. This study suggests that the Chinese firms' outward FDI location choice is a result of the interplay and the fit between the external legitimacy and the internal legitimacy.

This study has sought to make three contributions. First, it develops and tests a contingency conceptual framework by incorporating the two theoretical perspectives-the institutional theory and the strategic intent approach-contributing to the literature of both the institutional theory and strategic intent approach in the context of location choice by EMNEs. In this framework, resource-seeking intent of the investing firm as the firm's internal institutional factor interacts with political risk and economic freedom as the firm's external institutional forces in its 
influence on location choice of emerging economy MNEs. Empirical findings from this study suggest that successful pursuit of resource-seeking intent by an EMNE depends on how effective it can leverage its institutional advantages and overcome institutional constraints. Existing studies suggests that EMNEs respond to the institutional regime in the host countries in a manner different to their developed country counterparts, for example, they are more likely to locate in a host country with a high political risk [12] [14] [23] [24] [25]. Extending this line of research, our study posits that the way EMNEs respond to institutional constraints is influenced by strategic intent, such as resource-seeking intent. Second, our study contributes to the literature by emphasising the role played by embeddedness of institutional forces at a home country setting in making location choice. Studies highlight the heavy influence from the unique institutional forces of the home country as a significant feature of internationalisation for EMNEs [26] [27]. For the case of China, the state has a strong involvement in the firms' FDI activities [16] [28]. Our conceptualisations of political risk and economic freedom provide a framework to reflect home country embeddedness in the measurement of the concepts for institutional forces. Moreover, the empirical findings from our study regarding the opposite directions for interactive effects involving political risk and economic freedom demonstrates the influence of embeddedness from home country institutions in terms of both institutional advantages and institutional constraints to investing firms' location choice. Third, this study examines a three-way interaction between institutional forces and strategic intent. The empirical findings regarding this three-way interaction demonstrate a substituting effect between political risk and economic freedom in their interactions with resource-seeking intent to influence FDI location choice. The substituting effects revealed in this study highlight the complexity of tasks facing emerging economy firms in leveraging institutional advantages and overcoming institutional constraints in order to achieve the internal strategic intent when making an FDI location choice decision.

The empirical context is the outward FDI made by Chinese firms to sixty-two host countries. The rationale for this research setting is twofold. First, China offers an ideal case for research on outward FDI from emerging economies, as China has recorded as the most active emerging economy that contributes to the growing FDI in recent years [29]. Second, Chinese outward FDI has dramatically accelerated since this new century. A focus on this time period will help in gaining an understanding about the dynamic nature of Chinese outward FDI in general and its location choice in particular. Using panel data covering a period of dramatic growth of Chinese outward FDI (2003-2014), this study investigates the effects of resource-seeking intent in its interaction with political risk and economic freedom as two institutional forces.

\section{Theoretical Framework}

\subsection{Strategic Intent Approach}

The strategic intent approach has been used to address FDI activities from 
EMNEs [30] [31] [32] [34]. Following this approach, FDI activities are conducted for the pursuit of certain long-term strategic goals at firm level for the objective of maximising overall performance and of extending beyond setting up the most efficient subsidiaries in a foreign country [32] [33]. This approach was first initiated to describe the dramatic ascent by the Japanese firms through strategic behaviour in the market competition with their rivals in the western countries [35]. Strategic intent is regarded as an active and rational management process with a clear focus on the essence of winning in the market competition through improving competitive position relative to rivals [36]. The strategic intent approach takes global strategic arrangement into consideration for the decisions in FDI activities where the whole global business network, rather than a single transaction, is the unit of analysis. Several concepts are considered to be at the centre to the strategic intent approach: 1) ambitious strategic objectives, 2) making the strategic objective the first priority, and 3) making rational choice [34]. For the strategic decision on location choice, driven by the strategic intent to achieve firm-specific and thus heterogeneous strategic goals, an investing firm would locate its FDI activities at an optimal location where the location-specific advantages are able to facilitate attainment of its strategic goals.

Given the multiple facets of strategic intent for FDI involvement by EMNEs, such as entering new markets, building resource bases, expanding capabilities by learning and acquiring new knowledge, realising a firm's strategic transformation [30] [34], we focus on the resource-seeking intent as one of the most important strategic intent for FDI activity [37], which is defined as acquiring and securing a continual supply of natural resources from a foreign country, in order to provide industrial inputs into the downstream operations at home country, as internalisation theory on FDI emphasises the importance of equity-based control in exploitation of a scare natural resource over market exchange [38].

\subsection{Institutional Perspective}

The institutional perspective of FDI location choice views location choice as a means of conforming to the institutional environment and to the organisational routines of business practices in the host country [25] [39]. Empirical studies have provided a strong support to the notion that political and economic regulatory regimes in a host country have a significant influence on FDI inflows [40] [41]. Moreover, due to the effect of institutional embeddedness, the institutional environment in the home country is also a major shaping force for investing firm's FDI behaviour [8] [42].

Institutional systems are not unified or coherent [2]. The literature has highlighted that two types of regulatory force exert influence or authority over the way in which emerging economy firms locate their resources for FDI activities. The first is political risk [43] [44] and the other is economic freedom [42] [45]. This study intends to examine how these two forces in the institutional setting of both host and home countries interact with a firm's resource-seeking intent to influence location choice of outward FDI by EMNEs. 


\subsection{Resource Seeking Intent, Institutional Forces, and FDI Location Choice}

Through the lenses of the strategic intent and institutional perspectives, we focus on the mechanisms that remain largely unknown but important for understanding the strategic choices of FDI location for EMNEs. On the one hand, driven by the strategic intent to achieve firm-specific and thus heterogeneous strategic goals, the investing firm would locate FDI activities at an optimal location to facilitate attainment of these strategic goals. On the other hand, in response to the isomorphic pressure, the investing firm would place their FDI activities in a location where the institutional environment is less difficult for the firm to adapt to, making it easy for the firm to establish its legitimacy in the host country. As a result, there is an interaction between the institutional and strategic intent factors. Thus, the investing firm's FDI location choice is a result of interactive effects between its pursuit of the strategic intent at one hand and its response to the external institutional forces both in the host and home countries at the other.

As illustrated in Figure 1, a conceptual framework is developed to examine the impact of the interaction between Chinese MNEs' external institutional forces and internal resource-seeking intent on their choice of outward FDI locations. As a rational management process, strategic intent focuses on the pursuit of a certain long-term strategic goals to gain competitive advantage over rivals [46]. We first analyse the internalisation process of strategic resource-seeking goal at national level into resource-seeking intent of FDI activities at the level of investing firms. Then we hypothesise the interacting effect of resource-seeking with institutional forces in terms of political risk and economic freedom on the firm's location decision.

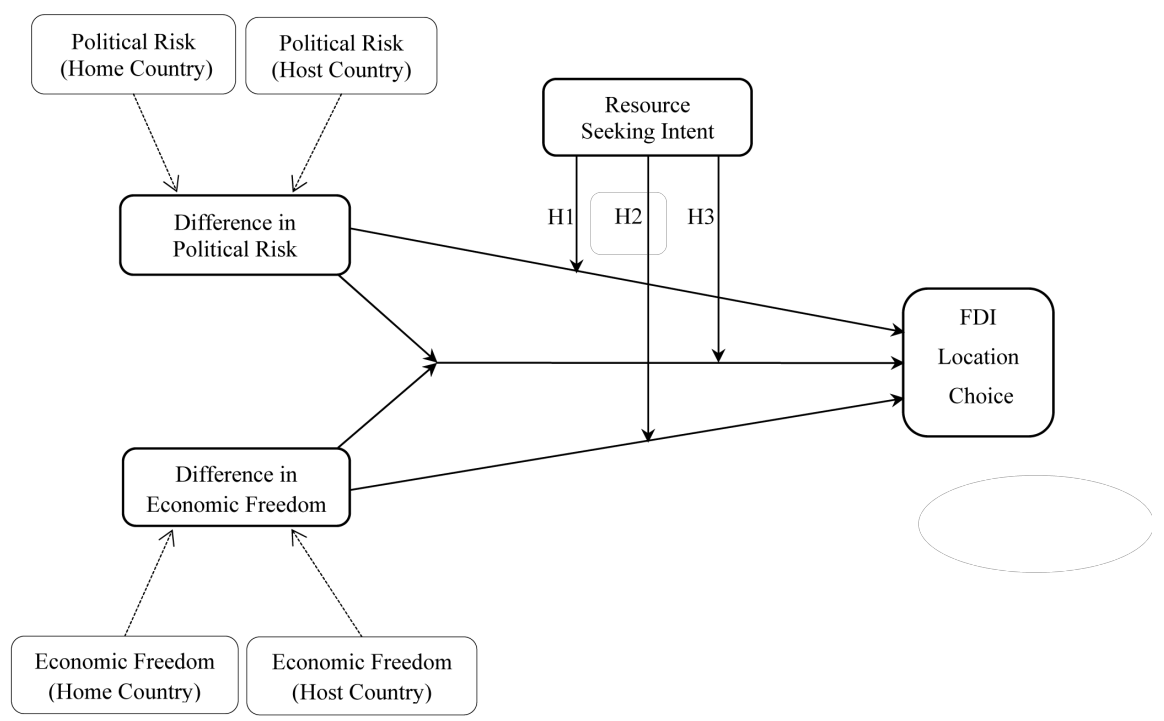

Figure 1. Conceptual framework: Resource seeking intent, institutional differences, and FDI location choices. 


\section{Hypothesis Development}

\subsection{Strategic Intent and Location Choice}

Studies have suggested that resource-seeking is one of the key strategic goals in motivating Chinese outward FDI [14] [39]. Although China is rich in its endowment of various natural resources as a geographically large country, its per capita availability of natural resources is rather low by international standard, especially mineral resources such as iron ore, aluminium, copper and petroleum [33]. Following rapid economic growth and industrialisation during the last three decades, China has become a major centre for manufacturing in the world and developed an almost insatiable appetite for various natural resources. It is evident that China faces severe shortage in natural resources to support its phenomenal growth and that there is a strong need for Chinese firms to acquire and secure a continual and large supply of raw material for its industrial operations [14].

The home country's national strategic goal of resource-seeking can be internalised into the resource-seeking intent of the investing firms, when involved in outward FDI, through the influence of institutional forces in the home country. Research on outward FDI from emerging economies has suggested that the institutional arrangements in the home country are one of the major shaping forces for FDI activities [15] [47] [48]. The institutional environment facing Chinese firms in their home country is strikingly different to that facing their counterparts in the western developed countries, and one of the major differences is that the state has a strong involvement in the economy and business in general and in FDI activities in particular [20] [28]. A distinct and highly dynamic institutional environment in the home country has significantly contributed to the uniqueness of Chinese outward FDI [49]. A majority of Chinese outward FDI were conducted by state-owned firms, and governmental approval/annual reporting of overseas operational matters were also required [31] [50]. State ownership can lead to a pursuit of the investing firms towards non-commercial objectives rather than business benefits driven by the political interests of the state [51].

In addition, through financial incentives, such as credit insurance and access to low-interest loans, the government may favour or discourage certain types of FDI based on its short-term or long-term policy agenda. Financial and other types of support from the government can provide investing firms with resource advantage to compensate their disadvantage in lack of firm-specific advantage in international competition [26] [52]. Government approval and annual reporting of overseas operational matters can direct the FDI activities towards particular locations and/or industries [31] [50]. By operating in and incorporating into the institutional arrangements of the home country, the embeddedness makes the investing firms become a part of the institutions in the home country. Consequently, the strategic need for natural resources at country level can be internalised into the strategic intent of resource-seeking for the investing firms. 


\subsection{Political Risk, Strategic Intent, and FDI Location Choice}

Political risk for FDI activity is defined as the likelihood that the host government might suddenly change the "rules of the game" in a way that adversely affects the interests of the foreign firm [53]. A government is more credible in its commitment to maintain political stability, when its actions are constrained by institutional checks and balances, which make it less likely to unilateral change regulations and rules [54]. Political risk in a host country is one of the major institutional factors that can hinder FDI inflow and associated business activities, as it generates a high degree of uncertainty with foreign ownership and increases asset exposure in the event of eventual expropriation [55]. In general, FDI prefers the government to be credibly committed to the stability of a set of rules and policies, especially property rights on investment, as a political stability reduces political risk of investing [56] [57].

However, the relationship between political risk and FDI location choice for EMNEs is more complex than the straightforward negative effects of political risk on location choice. Institutional setting at the home country may help in providing an explanation for the complexity in the relationship. There are institutional voids, such as the absence of specialized intermediaries and contract-enforcement mechanisms, in emerging economies [52]. Emerging country firms know how to work around the institutional voids because they have had years of experience doing so [58]. Further, EMNEs are often able to turn such experience of institutional voids to their competitive advantage over their competitors from developed countries in operating in an institutional environment with high political risk, because they tend to face a smaller liability of foreignness in such a host environment given institutional embededness from their home country [52]. Operating in a politically repressive and risky environment in their home country, Chinese investing firms may find that they can more readily establish institutional legitimacy in a foreign country with a similar political environment when competing with developed country MNEs in FDI activity [39]. The political embeddedness in the home country could be internalised into a type of firm specific advantages, which provides investing firms with expertise in adaptation to a similar institutional environment, characterised as high political volatility and bureaucratic intervention [24]. Thus, it is the difference in political risk between the host and home countries, rather than political risk in a host country alone, that would affect location choice.

Moreover, the behaviour pattern in terms of risk consideration of Chinese outward FDI may be significantly influenced by the pursuit of resource-seeking intent. First, perception of political risk has implications for decision-making in FDI activities [59]. When FDI location choice is driven by resource-seeking intent, political risk perceived by the investing firm would be assessed in association with its pursuit of natural resources. The strategic intent approach suggests that the firm would take its global strategic arrangement into consideration when engaged in FDI activities, rather than focusing on the risk at one specific 
location [46]. Second, as the resource-seeking intent is resulted from an internalisation of the national strategic goal, it serves interests of the nation-state as well as the firm itself, and thus managerial decisions in implementing this strategic intent would gain government backing. As a result, management executives of the investing firm will factor in the possibility that support from the government would be available when pursuing its strategic intent through FDI in a country with high political risk [20]. With perceived government support combined with the advantage of low-cost capital from soft budget constraints, the tolerance level of the investing Chinese firm towards political risk is likely to be moderated by strategic intent of resource-seeking [60].

In addition, "the resource curse hypothesis" [14] [61] may also be helpful in understanding the relationship between resource-seeking intent, political risk and the pattern of FDI location choice for EMNEs. This hypothesis implies an intertwined link between endowment of natural resources and high level of political risk in some developing countries. Consequently, driven by resource-seeking intent, the investing firm would be likely to locate its FDI activities in a country where the political risk is high. Therefore, we propose the following hypothesis:

Hypothesis 1. Difference in political risk between host and home countries interacts with resource-seeking intent of the investing firm to negatively influence location choice of Chinese outward FDI.

\subsection{Economic Freedom, Strategic Intent, and FDI Location Choice}

Market-supporting institutions impose a significant impact on FDI activities [42]. From an institutional perspective, a decision on location choice for multinationals is to determine favourable location where regulatory institutional constraints for economic activities are less repressive so that multinationals can more readily conform to the regulatory regime of the host country [39]. The institutional regime includes the legal framework and its enforcement in terms of business freedom, property rights, financial and taxation regime, and investment restriction [42]. With a high level economic freedom, the institutional arrangements provide a strong support to the voluntary exchange, which underpins an effective market mechanism, and the institutional arrangements are considered as "strong" or "good". Conversely, with a low level of economic freedom, the institutional arrangements are judged as "weak" or "poor" [41].

In general, investing foreign firms are subject to the constraints from the regulatory institutional arrangements in a host country [62]. Foreign firms can be affected by various discriminatory and restrictive policies from the host country government. For instance, the government is able to restrict foreign firms in their acquiring ownership of local firms, limit their access to local resources, require mandatory exporting of their products, and interfere with other operational matters [20]. When these institutional arrangements are strong and work smoothly in developed countries, their role becomes almost invisible and is 
faded away as "background" conditions for business operations, although highly critical [8]. Until more recently, market-supporting institutions in international business setting have been taken for granted [42]. With the rise of emerging economies in the world, more research attention has been paid to the institutions in these economies, especially since the turn of the new century [63] [64]. When the market-supporting arrangements have been malfunctioned in these emerging and transition economies, their deficiency becomes conspicuous [8]. As a result, EMNEs are motivated to enter into markets that are equipped with well-developed market-supporting institutions [32]. This tendency of location choice by emerging economy firms is known as "institutional escape" or "institutional arbitrage" [65].

From a host country perspective, investment into the natural resources sector is encouraged if exploration of the natural resources leads to economic growth. Prior researchers suggest that natural resources can either be beneficial [66] [67] [68], or have a significant negative effect on economic growth [69] [70]. Whether or not natural resources are beneficial for economic growth depends on the strength of the country's institutions, as institutions are the fundamental cause of economic growth [1]. Economic freedom is a key to increase prosperity and promotes growth and prosperity [66]. Therefore, a country that demonstrates high level of economic freedom is more likely to facilitate attainment of the resource-seeking intent by the EMNEs. This helps to synergise the interests of the host countries and the investing firms when seeking natural resources. As a result, firms that have stronger natural resource seeking intent are more likely to choose countries with high level of economic freedom as their investment location. The overall economic freedom in China is scored rather low. Thus, there is a considerable difference in the economic freedom between China and most other countries. A large difference in economic freedom between China and host countries means a high level of economic freedom in the host countries. The logic of above discussions leads to the following hypothesis:

Hypothesis 2. Difference in economic freedom between host and home countries interacts with resource-seeking intent of the investing firm to positively influence location choice of Chinese outward FDI.

\subsection{A Three-Way Interaction Effect}

Institutional theory suggests that organisations have to deal with institutional constraints from different dimensions when they attempt to establish legitimacy in a given environment [2]. Hence, investing firms are likely to face a combined impact from different dimensions of the regulatory institutional regime in the host country, which go beyond the separating interaction influence we proposed above. Prior studies have examined the interacting influence between firm's internal factors, such as firm resources and capabilities, and institutional forces, such as state ownership and government involvement, on FDI decisions [14] [28]. However, it is a largely underexplored area regarding how different institu- 
tional forces join together through either reinforcing or substituting each other's role and interact with firm's internal factors to shape the ability of EMNEs' expansion into foreign markets when they are driven by a strong resource-seeking intent. More specifically, it is still unclear how political risk and economic freedom in the regulatory regime jointly interact with resource-seeking intent in order to influence FDI decisions for MNEs from emerging economies, such as China.

Different forces in a regulatory institutional regime, such as political risk and economic freedom, may influence investing firm's FDI decisions towards opposing directions. On the one hand, institutional embeddedness in the home country [15] [24] and strong support from home institutions through mechanisms such as government involvement and state ownership [20] enables the investing firms to develop firm specific capabilities in operating in a politically more repressive environment. These firm capabilities would become a type of competitive advantage when competing with rivals from developed countries in a host country with high political risk. As a result, EMNEs are more likely to invest in a host country with high political risk when they are driven by strong resource-seeking intent. On the other hand, the tendency of "institutional escape" by EMNEs [32] [65] suggests that EMNEs are likely to invest in a host country with high level of economic freedom in order to facilitate effective pursuit resource-seeking intent. In light of the arguments regarding opposing directions of political risk and economic freedom in their influence on FDI decisions, we propose that political risk and economic freedom would join together by substituting each other's role in their interactions with resource-seeking intent on FDI decisions. Thus,

Hypothesis 3. There is a three-way interaction effect between political risk, economic freedom and resource-seeking intent. Compared with other circumstances, Chinese MNEs are more likely to invest in a host country with lower difference in political risk and high difference in economic freedom to the home country when resource-seeking intent is stronger.

\section{Research Methods}

\subsection{Research Setting and Data Method}

The three hypotheses are empirically tested in the context of outward FDI from China to worldwide sixty-two host countries covering a twelve-year period from 2003 to 2014. Two criteria were established for selecting sample host countries. The first is the intensity of Chinese FDI. All the countries included in the sample were ranked as the major destinations for Chinese outward FDI and recorded significant Chinese FDI value during the period under study. We excluded several tax havens from our sampling, such as the British Virgin Islands, the Cayman Islands, and The Bermuda Islands. The second consideration is data availability. Several countries or region, such as Iran, and Macao, also recorded significant value of Chinese FDI, but were excluded from the data, because there 
were too many missing values for explanatory variables for these countries and region.

\subsection{Dependent Variable}

This study investigates the impact factors for location choice of Chinese outward FDI, and thus location choice of Chinese outward FDI is the dependent variable. The dependent variable is measured through the proxy of FDI stock from China in a host country. FDI stock, rather than FDI flow, was adopted as the measurement, because stock values exclude the divestment in a host country and provide a more accurate measure of location distribution of FDI. Annual FDI stock invested by Chinese firms in the sixty-two sample countries covering the period under study was operated as dependent variable and empirical data were sourced from MOFCOM, a Chinese official on-line database of Ministry of Commerce, the People's Republic of China (MOFCOM, 2015).

\subsection{Explanatory Variables}

The variable of political risk is measured by a composite variable generated from multiple dimensional indicators measuring political governance from Worldwide Governance Indicators, published by the World Bank (2015). This source has been widely used in literature as the measurement for political risk [14] [70]. Six component items were adopted to configure this variable, including: 1) government effectiveness, 2) political stability, 3) absence of violence/terrorism, 4) regulatory quality, 5) rule of law, and 6) control of corruption. Annual data for these six component items for the 62 sample countries were taken from the database of Worldwide Governance Indicators, the World Bank (2015). A correlation test was performed to test the compatibility of these measurement items. The results revealed that scores of the six measurement items for the sample countries during the period 2003-2014 were highly correlated, with all correlation coefficients greater than 0.68 , while the highest is 0.97 . Thus, the six component items were merged to create a composite variable as the proxy for political risk, and mean scores of the six items are used as the measurement.

Several steps were taken for a better operation of the variable. First, the original values for the six items in the World Bank data ranged from -2.5 to 2.5 (a higher score means higher political stability and less political risk). In order to more accurately gauge the concept of political risk, an offset value of 2.5 was added to each original item score. Second, the original score measures political stability and a higher score indicates a lower level of political risk in a host country. To be in accordance with the concept of political risk, a value of 5 is used to subtract each individual score of the composite variable. As a result, direction of the original measure was reversed and a higher score indicates a higher level of political risk. Third, as suggested in our hypotheses, relative difference of political risk between the home and host countries, rather than the political risk in a host country, is to be investigated as a variable of influencing location choice of 
Chinese outward FDI. Relative political risk is taken as the difference of composite values for political risk between China and a host country.

Economic freedom is operated as a composite variable and its measurement items were sourced from the Index of Economic Freedom [71]. This data source provides information about a broad range of economic regulatory regime, focusing on the freedom of individuals and companies in a country to pursue business interests, and is extensively used in literature [42] [45]. The original data source contains 50 independent measurement indicators, which are merged into 10 category items. The theoretical consideration of this study suggests that conceptualisation of economic freedom focuses on the economic regulatory regime which promotes FDI activities in a host country. Thus, four category items that are more closely relevant to FDI activities were selected, including: 1) business freedom, 2) investment freedom, 3) financial freedom, and 4) property rights. The original data measures economic freedom on a scale range from 0 to 100 , with a higher value representing higher level of economic freedom. A correlation test was conducted to assess the four component items. The results suggest that measurement values are highly correlated for all the sample countries during the period under study, with the range for correlation coefficients between 0.692 and 0.831 . Thus, the four component items were merged into a composite variable, acting as proxy for economic freedom. Similar to the case of operating political risk variable, the variable of difference in economic freedom between China and the host country was measured and operated.

The variable of resource seeking intent was introduced to capture the strategic intent of outward FDI in gaining access to natural resources. Richness in ore reserves represents the endowment of natural resources in a country. The ratio of ore and metal exports to merchandise exports in a country is a reflection of the richness in natural resources in the country, and can be used as a proxy to capture strategic intent of resource-seeking of the investment firm. This proxy has been widely adopted in the literature as a measurement of resource-seeking motive [14] [15] [72] [73]. Data for this variable were sourced from the database World Development Indicator 2015, developed by World Bank (2015).

\subsection{Control Variables}

A number of control variables were introduced in the regression estimations to reveal the impacts of main variables. Chinese outward FDI has demonstrated a strong market seeking motivation [23] [28] [74]. Market seeking FDI is attracted by large market size and high potential for market growth [39]. The variables of GDP, GDP per capita, GDP growth and population have been extensively used in literature as proxies for market size and market potential. This study adopted these four variables to control market-seeking motive of Chinese FDI. The rationale for introducing these variables is that GDP and population represent the absolute market size, GDP per capita stands for the relative market size, and GDP growth measures the potential market growth. Inflation was also included 
as a control variable because of its influence on FDI activity. A high inflation rate tends to reduce FDI inflows to a host country [23], as it implies instability and uncertainty of the macroeconomic condition. Data for all five control variables were sourced from the database World Development Indicator 2013, developed by World Bank (2013). In summary, Table 1 provides a description of the hypotheses developed in this study, their theoretical justification, the proxies used to measure the relevant variables, and the data sources.

\subsection{Modelling Method and Preliminary Tests}

The panel data analysis was adopted as the method for regression modelling. This method is able to combine information taken from individual units (each country in this case) with information collected over a time series. In this study, the use of panel data method pooled together cross-sectional data of 62 countries over a period from 2003 to 2014. The advantage of the panel data regression modelling is that it allows idiosyncrasies (heterogeneity) among units of research subject (individual countries in this study) to be considered and controlled, thus avoiding the problems of misspecification when using other regression methods [75].

According to the conceptual framework and the variables discussed above, a regression model is formulated as bellows:

$$
\begin{aligned}
\text { FDIStock }_{i t}= & \alpha_{i}+\beta \text { Prisk }_{i t}+\beta \text { Efreedom }_{i t}+\beta \text { Resource }_{i t}+\beta \mathrm{GDP}_{i t} \\
& +\beta \mathrm{GDPP}_{i t}+\beta \mathrm{GDPG}_{t t}+\beta \text { Population }_{i}+\beta \text { Inflation }_{i t}+u_{i t}
\end{aligned}
$$

where $i=1, \cdots, 62$ stands for the host country, and $t=2003, \cdots, 2014$ represents the year. $\alpha_{i}$ represents the constant and $u_{i t}$ represents unobserved disturbance.

\begin{tabular}{|c|c|c|c|c|}
\hline Variables & Proxy & $\begin{array}{l}\text { Variable } \\
\text { type }\end{array}$ & Theoretical justification & Data source \\
\hline FDI location choice & Annual FDI Stock in the host country & Dependent & & $\begin{array}{l}\text { MOFCOM (2015). Ministry of } \\
\text { Commerce, China }\end{array}$ \\
\hline $\begin{array}{l}\text { Difference in } \\
\text { political risk }\end{array}$ & $\begin{array}{l}\text { Prisk: Composite variable, relative difference of } \\
\text { political risk between host and home countries }\end{array}$ & Explanatory & $\begin{array}{l}\text { Institutional force in the } \\
\text { host and home countries }\end{array}$ & $\begin{array}{l}\text { World Bank (2015), Worldwide } \\
\text { Governance Indicator }\end{array}$ \\
\hline $\begin{array}{l}\text { Difference in } \\
\text { economic freedom }\end{array}$ & $\begin{array}{c}\text { Efreedom: Composite variable, relative difference } \\
\text { of Economic Freedom between host and home } \\
\text { countries }\end{array}$ & Explanatory & $\begin{array}{l}\text { Institutional force in the } \\
\text { host and home countries }\end{array}$ & $\begin{array}{l}\text { The Heritage Foundation (2015), } \\
\text { Index of Economic Freedom }\end{array}$ \\
\hline $\begin{array}{l}\text { Resource seeking } \\
\text { intent }\end{array}$ & $\begin{array}{l}\text { Resource seeking intent: the ratio of ore and metal } \\
\text { exports to merchandise export in the host country }\end{array}$ & Explanatory & $\begin{array}{l}\text { Strategic intent of invest } \\
\text { firms }\end{array}$ & $\begin{array}{l}\text { World Bank (2015), World } \\
\text { Development Indicator } 2015\end{array}$ \\
\hline GDP & GDP: GDP in the host country & Control & $\begin{array}{l}\text { Market-seeking: Abso- } \\
\text { lute market size }\end{array}$ & $\begin{array}{l}\text { World Bank (2015), World } \\
\text { Development Indicator } 2015\end{array}$ \\
\hline GDP growth & GDPG: GDP growth rate in the host country & Control & $\begin{array}{l}\text { Market-seeking: Market } \\
\text { growth potential }\end{array}$ & $\begin{array}{l}\text { World Bank (2015), World } \\
\text { Development Indicator } 2015\end{array}$ \\
\hline GDP per capital & GDPP: GDP per capita in the host country & Control & $\begin{array}{c}\text { Market-seeking: Relative } \\
\text { market size }\end{array}$ & $\begin{array}{l}\text { World Bank (2015), World } \\
\text { Development Indicator } 2015\end{array}$ \\
\hline Population & Population of the host country & Control & Market-seeking & $\begin{array}{l}\text { World Bank (2015), World } \\
\text { Development Indicator } 2015\end{array}$ \\
\hline Inflation & Annual inflation rate & Control & Macroeconomic stability & $\begin{array}{c}\text { World Bank (2015), World } \\
\text { Development Indicator } 2015\end{array}$ \\
\hline
\end{tabular}

Table 1. Description of hypotheses, variables and data sources. 
For the panel data analysis, it is important to decide which model specification to use between the fixed effect and random effect models. Following [75], a Hausman test was performed. The Hausman test resulted in a large and significant Hausman statistic, indicating the null hypothesis is rejected. This result demonstrates that the idiosyncrasies in the across-section data need to be controlled. Thus, fixed effect model specification was chosen for modelling estimation. In this study, the fixed two-way method was used to fix cross sectional effects (individual countries) and time effects (different years).

Table 2 provides the descriptive statistics and correlation matrix for the variables used in the study. As shown in the table, standard deviation for the three variables of FDI stock, GDP and population are rather large, indicating existence of extreme values for the three variables. In order to avoid the potential bias of outliers, we adopt the logarithm transformation for values of the three variables before entering them into regression modelling. Correlation coefficients for most explanatory variables are rather low. However, the three coefficients for correlations between political risk and economic freedom, between political risk and GDP per capita, and between economic freedom and GDP per capita, are above 0.60 . The rather high correlation between political risk and economic freedom demonstrates a close relationship between quality of institutional arrangements and country risk for business transactions. The high correlations between political risk and GDP per capita, and between economic freedom and GDP per capita, reflect a close relationship between institutional quality, political risk and economic development level. However, for regression estimation, these highly correlated variables indicate the potential multicollinearity [76]. If untreated, the presence of multicollinearity will lead to the problem of indistinguishable effects of individual explanatory variables on dependent variable. To detect and control the potential multicollinearity, a multiple regression analysis was performed to assess the variance inflation factor (VIF). As shown in Table 1 , VIF value for all explanatory variables is well below the cutting-point of 10 , with the largest one being 4.25 , indicating that multicollinearity is not a concern for the data [77].

Table 2. Descriptive statistics and correlation matrix.

\begin{tabular}{|c|c|c|c|c|c|c|c|c|c|c|c|}
\hline Variables & Mean & S.D. & VIF & 1 & 2 & 3 & 4 & 5 & 6 & 7 & 8 \\
\hline FDI Stock & 170,085 & $1,316,394$ & & & & & & & & & \\
\hline 1) Difference in political risk & -0.3742 & 0.99422 & 4.053 & 1 & & & & & & & \\
\hline 2) Difference in economic freedom & 23.0868 & 19.1739 & 4.232 & -0.785 & 1 & & & & & & \\
\hline 3) Resource seeking intend & 26.9407 & 29.1204 & 1.321 & 0.411 & -0.392 & 1 & & & & & \\
\hline 4) GDP & $6.507 \mathrm{E} 11$ & $1.06908 \mathrm{E}$ & 1.503 & -0.337 & 0.309 & -0.167 & 1 & & & & \\
\hline 5) GDPG & 4.4132 & 4.12245 & 1.256 & 0.283 & -0.269 & -0.254 & -0.209 & 1 & & & \\
\hline 6) GDPP & 12850 & 15,928 & 4.251 & -0.816 & 0.722 & 0.116 & 0.474 & -0.348 & 1 & & \\
\hline 7) Population & $60,958,141$ & 14999E4 & 1.169 & 0.072 & -0.095 & -0.046 & 0.273 & -0.056 & 0.100 & 1 & \\
\hline 8) Inflation & 6.3088 & 6.51987 & 1.038 & 0.082 & -0.093 & 0.001 & -0.019 & -0.041 & -0.102 & -0.016 & 1 \\
\hline
\end{tabular}




\section{Modelling Results}

\subsection{Estimation Results}

Table 3 provides the results of empirical modelling results. A hierarchical modelling method was adopted and eight model equations were estimated. Model 1 is a baseline model, with five control variables included to provide a reference basis against which to compare the results from hypotheses-testing equations. This regression equation is statistically significant and has a rather high value of adjusted squared $\mathrm{R}$ at 0.6413 , indicating a strong explanatory power of the model. The results suggest that the control variables, relating to the market and macroeconomic situations at a host country, are able to provide an explanation for location choice of Chinese outward FDI.

Models 2 and 3 add main effect of resource-seeking and two interaction variables of political risk and economic freedom. Models 4 and 5 test the two-way interaction effects, as we separate the testing of interaction effects of political risk and economic freedom to avoid multicollinearity. Model 6 presents an integrated analysis. Model 7 tests the three-way interaction effect and Model 8 integrates control variables, independent variables, two-way and three-way interaction effects.

Turning to hypothesis-testing, Hypothesis 1 proposes that political risk interacts with resource-seeking intent to influence FDI location choice in such a way that with a stronger resource-seeking intent, a Chinese firm would be more likely to invest in a host country that has smaller difference in political risk with

Table 3. Results of regression analysis.

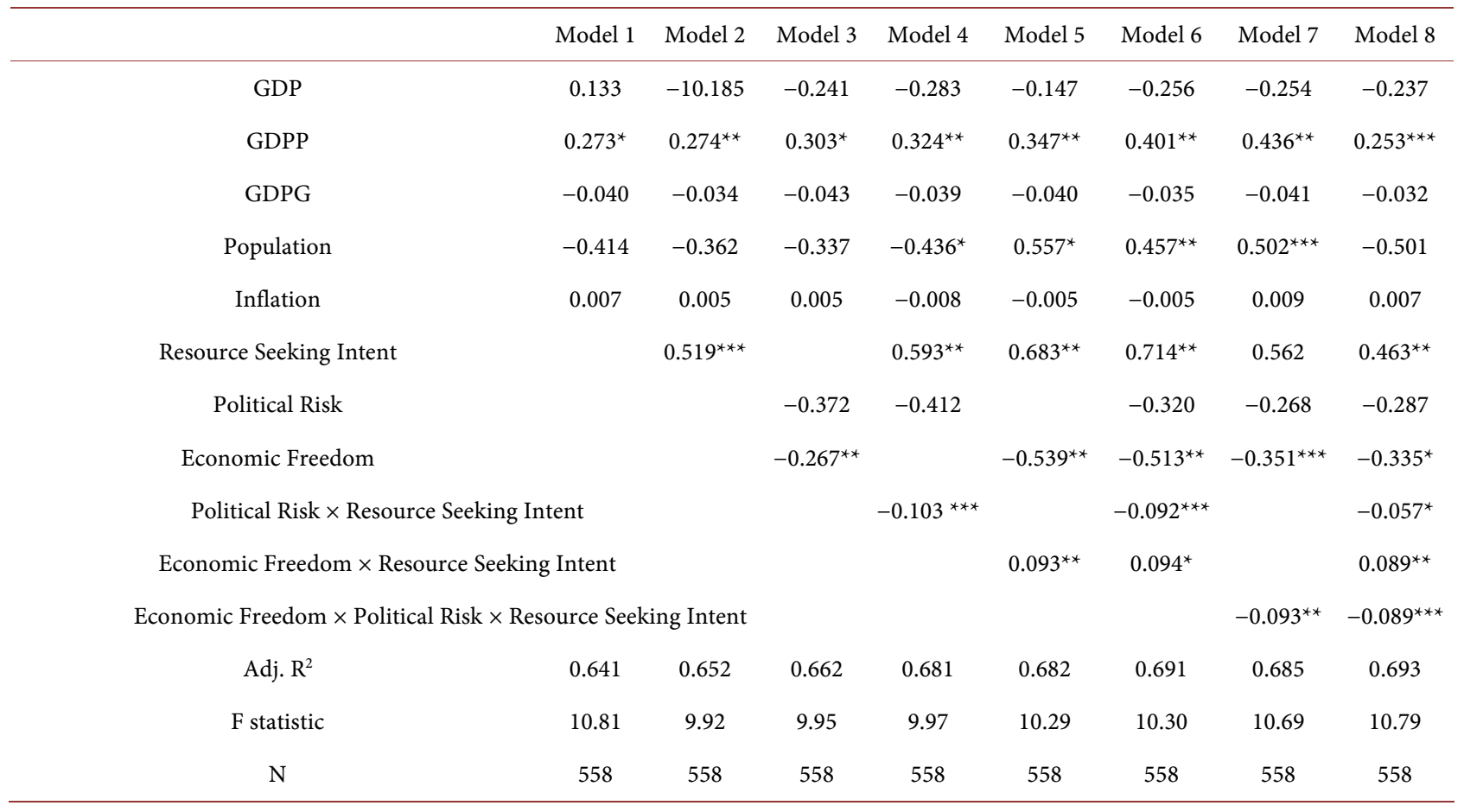

Values are standardized regression coefficient. ${ }^{*} \mathrm{p}<0.05 ;{ }^{* *} \mathrm{p}<0.01 ;{ }^{* *} \mathrm{p}<0.001$. 
the home country. As shown in Model 4, the interaction term of resource-seeking intent and difference in political risk between a host and home countries is negative and highly significant $(\mathrm{p}<0.01)$, although the coefficient is rather small. This result provides evidence that, when resource-seeking intent is stronger, an investing firm is more likely to invest in a host country that has smaller difference to the home country in political risk. Thus, Hypothesis 1 is supported. Since China as the home country scored rather high in the measurement of political risk (Wold Bank 2015), this result suggests that an investing firm tends to locate its FDI activities in a host country that has a high political risk when resource-seeking intent is strong.

Hypothesis 2 proposes that economic freedom interacts with resource-seeking intent in such a way that when FDI is driven by a stronger resource-seeking intent, a Chinese firm would be more likely to invest in a host country that has bigger difference in economic freedom with the home country. As shown in Model 5, the interaction term of resource-seeking intent and difference in economic freedom is significant $(\mathrm{p}<0.05)$ and has a positive sign, indicating that an investing firm is likely to locate its FDI activities in a host country that has bigger difference in economic freedom with the home country when resource-seeking intent is stronger. In considering that the direct effect from the variable of difference in economic freedom is significant but negative, the interaction effect of resource-seeking intent is highly strong so that the direction of effecting on FDI location choice is changed. Thus, Hypothesis 2 is supported. Since China as the home country scored rather low in the measurement of economic freedom, this result suggests that an investing firm is more likely to invest in a host country that has a high level of economic freedom when resource-seeking intent is strong.

Hypothesis 3 proposes a three-way interaction of resource-seeking intent, political risk and economic freedom in their effect on FDI location choice. This hypothesis presents a substituting effect between political risk and economic freedom in their interaction with resource-seeking intent. As shown in Model 7, the three-way interaction term is significant $(\mathrm{p}<0.05)$ and has a negative sign, indicating a trade-off relation between political risk and economic freedom in their interaction with resource-seeking intent. That is, when resource-seeking intent is stronger, an EMNE is likely to locate its FDI activities in a host country that has a smaller difference in political risk but bigger difference in economic freedom with the host country. Thus, Hypothesis 3 is supported.

\subsection{Robustness Checks}

We used FDI stock, instead of FDI flow, to measure the dependent variable. Unlike the FDI flow, FDI stock at a particular year could be highly dependent on the FDI stock at the previous year. We controlled for possible estimation biases by adopting a dynamic panel data analysis to account for the influence of FDI stock in previous years. We used lagged independent variables to reduce the po- 
tential endogeneity bias, if any. The results remained qualitatively the same, indicating the robustness of our modelling estimations. Hong Kong has recorded as the largest destination for Chinese FDI. To consider the distorting impact played by Chinese FDI to Hong Kong as an outlier, we excluded Chinese FDI to Hong Kong in our preliminary model tasting. Our empirical results can still hold when Hong Kong is excluded from our sample.

\section{Discussion and Conclusions}

Recognising that the EMNEs are increasingly using FDI activities as a strategic means to improve their competitive advantage and to catch up with their counterparts from developed countries [20] [32] [34] [78] and that institutional arrangements in both host and home countries impose constraints on strategic decisions regarding FDI activities [20] [42] [79], research attention in recent years has been paid to the research on the joint influence of institutional forces and the internal variables drawn from a strategic intent factors. However, more likely than not, studies accommodate the various factors drawn from external and internal perspectives together and assess their direct, parallel, and separate effects on FDI strategies [15] [20] [31]. Our study aims to advance international business research by advocating an interactive view of these two approaches and developing a contingency model on FDI location choice through incorporating the institutional and strategic intent perspectives. This study makes several contributions to the literature.

First, our study offers an integrated analysis on the conditions in terms of regulatory institutional regimes for effective pursuit of the investing firm's resource-seeking intent. Findings from this study demonstrate how successful implementation of strategic intent is achieved through leveraging the institutional advantages and overcoming the institutional constraints, and thus enrich the external conditions perspective of strategic intent. The strategic intent perspective emphasises the role of strategic intent in decisions for FDI activities by EMNEs [31] [32] [34] and the institutional approach highlights the constraints of institutional arrangements on strategic choices of firms [8] [80]. Following these two streams of research, our study finds that effective attainment of resource-seeking intent is contingent on the institutional environment both in host and home countries. This study contributes to the literature by examining in greater depth the interactive effects between resource-seeking intent and two dimensions of regulatory institutional regime as it offers a framework to theoretically investigate the joint influence from strategic intent and institutions on FDI decisions by EMNEs. The empirical findings regarding the two-way interactive effects between resource-seeking intent and the two aspects of regulatory institutions suggests that successful pursuit of resource-seeking intent depends on how effective an EMNE can leverage its institutional advantages and overcome institutional constraints it faces.

Second, our study contributes to current literature by shedding light on the 
significant role played by the home institutions in influencing FDI behaviour of EMNEs. Researchers call for attention to the influence of home institutions [26] [28] [79]. Our study extends this line of research. A prominent finding from this study is that the impacting directions are opposite each other for the two interactive effects between political risk and resource-seeking intent at one side and between economic freedom and resource-seeking intent at the other side. These results demonstrate the influence of embeddedness of home regulatory regime in terms of both institutional advantages and institutional constraints. The influence of embeddedness revealed in our study reflects the suggestion that home institutions can be internalised into the domestic firms through being embedded in the institutional environment so that they are becoming a prominent part of the institutional regime [20].

Third, previous studies seldom explore the interplay of different dimensions of regulatory institutional regime in their interactions with EMNEs' strategic intent. Our study sheds light on this underexplored area. Supporting the three-way interactive effect hypothesis, findings from this study demonstrates a substituting relation between political risk and economic freedom in their interactions with investing firm's resource-seeking intent. On the one hand, to leverage their institutional advantages, EMNEs tend to locate their FDI activities in a host country with a high level of political risk (thus, smaller difference with the home country) in their pursuit of resource-seeking intent. On the other hand, to overcome the institutional constraints imposed by the home institutional regime, they tend to invest in a host country with a high level of economic freedom (thus, bigger difference with the home country). The findings regarding this substituting relation extends previous studies by revealing the complexity of balancing the two tasks facing emerging economy MNEs in terms of leveraging institutional advantages and overcoming institutional constraints.

Several limitations in the study need to be discussed and addressing these limitations leads to the avenues for further research on this topic. First, findings of this study are based on a rather narrow research setting of outward FDI from China as an emerging economy, as the empirical testing of the interaction model was achieved in the context of Chinese outward FDI in the sixty-two countries for a period of ten years in this study. Further research could be conducted in order to test applicability of the conceptual framework at a broader research setting of MNEs from more emerging economies. Research of testing the conceptual framework on FDI location choice by MNEs from other emerging economies, such as India, Brazil, Russia, will more effectively broaden the empirical base of the conceptual framework of interaction. Second, not all investing firms have strategic intent to guide their FDI behaviour, and the extent of strategic intent for different firms is also different, depending on their external and internal conditions. These differences are difficult to distinguish and measure when relying on aggregate statistical data. Data sourced at firm level will be helpful in solving this problem. 


\section{Acknowledgements}

This research was financially supported by Humanities and Social Sciences Foundation, Ministry of Education, China (grant No. 16YJC630053) and Shaanxi Social Science Foundation, China (grant No. 2017S019).

\section{References}

[1] North, D.C. (1990) Institutions, Institutional Change and Economic Performance. Cambridge University Press, Cambridge. https://doi.org/10.1017/CBO9780511808678

[2] Scott, W.R. (2001) Institution and Organisations. 2nd Edition, Sage Publications, London.

[3] Hamel, G. and Prahaled, C.K. (1989) Strategic Intent. Harvard Business Review, 67, 63-67.

[4] Cui, L., Meyer, K.E. and Hu, H.W. (2014) What Drives Firms' Intent to Seek Strategic Assets by Foreign Direct Investment? A Study of Emerging Economy Firms. Journal of World Business, 49, 488-501. https://doi.org/10.1016/j.jwb.2013.12.003

[5] Gaur, A., Kumar, V. and Singh, D. (2014) Institutions, Resources, and Internationalization of Emerging Economy Firms. Journal of World Business, 49, 12-20.

https://doi.org/10.1016/j.jwb.2013.04.002

[6] Meyer, K.E. and Thaijongrak, O. (2013) The Dynamics of Emerging Economy MNEs: How the Internationalisation Process Model Can Guide Future Research. Asia Pacific Journal of Management, 30, 1125-1153. https://doi.org/10.1007/s10490-012-9313-9

[7] Meyer, K.E. (2015) What Is "Strategic Asset Seeking FDI"? Multinational Business Review, 23, 57-66. https://doi.org/10.1108/MBR-02-2015-0007

[8] Peng, M.W., Wang, D.Y.L. and Jiang, Y. (2008) An Institution-Based View of International Business Strategy: A Focus on Emerging Economies. Journal of International Business Studies, 39, 920-936. https://doi.org/10.1057/palgrave.jibs.8400377

[9] Jain, N.K., Kothari, T. and Kumar, V. (2016) Location Choice Research: Proposing New Agenda. Management International Review, 56, 303-324. https://doi.org/10.1007/s11575-015-0271-6

[10] Nielsen, B.B., Asmussen, C.G. and Weatherall, C.D. (2017) The Location Choice of Foreign Direct Investments: Empirical Evidence and Methodological Challenges. Journal of World Business, 52, 62-82. https://doi.org/10.1016/j.jwb.2016.10.006

[11] Buckley, P.J. and Munjal, S. (2017) The Role of Local Context in the Cross-Border Acquisitions by Emerging Economy Multinational Enterprises. British Journal of Management, 28, 372-389. https://doi.org/10.1111/1467-8551.12231

[12] Buckley, P.J., Yu, P., Liu, Q., Munjal, S. and Tao, P. (2016) The Institutional Influence on the Location Strategies of Multinational Enterprises from Emerging Economies: Evidence from China's Cross-Border Mergers and Acquisitions. Management and Organization Review, 12, 425-448.

[13] Cui, L. (2016) The Primacy of Institutional Explanation of Chinese Outward FDI: Is It Understated or Overstated? Management and Organization Review, 12, 457-467. https://doi.org/10.1017/mor.2016.22

[14] Ramasamy, B., Yeung, M. and Laforet, S. (2012) China's Outward Foreign Direct Investment: Location Choice and Firm Ownership. Journal of World Business, 47, 17-25. https://doi.org/10.1016/j.jwb.2010.10.016 
[15] Buckley, P.J., Devinney, T.M. and Louviere, J.J. (2007) Do Managers Behave the Way Theory Suggests? A Choice-Theoretic Examination of Foreign Direct Investment Location Decision-Making. Journal of International Business Studies, 38, 1069-1094. https://doi.org/10.1057/palgrave.jibs.8400311

[16] Duanmu, J.L. (2012) Firm Heterogeneity and Location of Chinese Multinationals. Journal of World Business, 47, 64-72. https://doi.org/10.1016/j.jwb.2010.10.021

[17] Greenwood, R. and Hinings, C. (1996) Understanding Radical Organizational Change: Bringing Together the Old and the New Institutionalism. Academy of Management Review, 21, 1022-1054.

[18] Greenwood, R. and Suddaby, R. (2006) Institutional Entrepreneurship in Mature Fields: The Big Five Accounting Firms. Academy of Management Journal, 49, 27-48. https://doi.org/10.5465/AMJ.2006.20785498

[19] Peng, M.W., Sun, S.L., Pinkham, B. and Chen, H. (2009) The Institution-Based View as a Third Leg for a Strategy Tripod. Academy of Management Perspective, 23, 63-81. https://doi.org/10.5465/AMP.2009.43479264

[20] Cui, L. and Jiang, F. (2012) State Ownership Effect on Firms' FDI Ownership Decisions under Institutional Pressure: A Study of Chinese Outward-Investing Firms. Journal of International Business Studies, 43, 264-284. https://doi.org/10.1057/jibs.2012.1

[21] Westney, D.E. (1993) Institutionalization Theory and the Multinational Corporation. In: Ghoshal, S. and Westney, D.E., Eds., Organizational Theory and the Multinational Corporation, St. Martin's, New York, 53-76. https://doi.org/10.1007/978-1-349-22557-6 3

[22] Kostova, T. and Zaheer, S. (1999) Organizational Legitimacy under Conditions of Complexity: The Case of the Multinational Enterprise. Academy of Management Review, 24, 64-81.

[23] Buckley, P.J., Clegg, L.J., Cross, A.R., Liu, X., Voss, H. and Zheng, P. (2007) The Determinants of Chinese Outward Foreign Direct Investment. Journal of International Business Studies, 38, 499-518. https://doi.org/10.1057/palgrave.jibs.8400277

[24] Buckley, P.J., Cross, A.R., Hui, T., Liu, X. and Voss, H. (2008) Historic and Emergent Trends in Chinese Outward Direct Investment. Management International Review, 48, 715-747. https://doi.org/10.1007/s11575-008-0104-y

[25] Quer, D., Claver, E. and Rienda, L. (2012) Political Risk, Cultural Distance, and Outward Foreign Direct Investment: Empirical Evidence from Large Chinese Firms. Asia Pacific Journal of Management, 29, 1089-1104. https://doi.org/10.1007/s10490-011-9247-7

[26] Luo, Y., Xue, Q. and Han, B. (2010) How Emerging Market Governments Promote Outward FDI: Experience from China. Journal of World Business, 45, 78-79.

[27] Peng, M.W. (2012) The Global Strategy of Emerging Multinationals from China. Global Strategy Journal, 2, 97-107. https://doi.org/10.1002/gsj.1030

[28] Wang, C., Hong, J., Kafouros, M. and Boateng, A. (2012) What Drives Outward FDI of Chinese Firms? Testing the Explanatory Power of Three Theoretical Frameworks. International Business Review, 21, 425-438. https://doi.org/10.1016/j.ibusrev.2011.05.004

[29] UNCTAD (2013) World Investment Report 2013: Global Value Chains: Investment and Trade for Development. United Nations, New York.

[30] Cui, L. and Jiang, F. (2009) FDI Entry Mode Choice of Chinese Firms: A Strategic Behaviour Perspective. Journal of World Business, 44, 434-444. 
https://doi.org/10.1016/j.jwb.2008.11.004

[31] Deng, P. (2009) Why Do Chinese Firms Tend to Acquire Strategic Assets in International Expansion? Journal of World Business, 44, 74-84.

https://doi.org/10.1016/j.jwb.2008.03.014

[32] Luo, Y. and Tung, R.L. (2007) International Expansion of Emerging Market Enterprises: A Springboard Perspective. Journal of International Business Studies, 38, 481-498. https://doi.org/10.1057/palgrave.jibs.8400275

[33] Deng, P. (2007) Investing for Strategic Resources and Its Rationale: The Case of Outward Direct Investment from Chinese Companies. Business Horizons, 50, 71-78. https://doi.org/10.1016/j.bushor.2006.07.001

[34] Rui, H. and Yip, G.S. (2008) Foreign Acquisitions by Chinese Firms: A Strategic Intent Perspective. Journal of World Business, 43, 213-226. https://doi.org/10.1016/j.jwb.2007.11.006

[35] Hamel, G., Doz, Y.L. and Prahalad, C.K. (1989) Collaborate with Your Competitors-And Win. Harvard Business Review, 67, 133-139.

[36] Kogut, B. (1988) Joint Venture: Theoretical and Empirical Perspectives. Strategic Management Journal, 9, 319-332. https://doi.org/10.1002/smj.4250090403

[37] Dunning, J. (1993) Multinational Enterprises and the Global Economy. Addison-Wesley, Wokingham.

[38] Buckley, P.J. and Casson, M. (1976) The Future of Multinational Enterprises. Macmillan, London. https://doi.org/10.1007/978-1-349-02899-3

[39] Kang, Y. and Jiang, F. (2012) FDI Location Choice of Chinese Multinationals in East and Southeast Asia: Traditional Economic Factors and Institutional Perspective. Journal of World Business, 47, 45-53. https://doi.org/10.1016/j.jwb.2010.10.019

[40] Grosse, R. and Trevino, L.J. (2005) New Institutional Economics and FDI Location in Central and Eastern Europe. Management International Review, 45, 123-145.

[41] Pajunen, K. (2008) Institutions and Inflows of Foreign Direct Investment: A Fuzzy-Set Analysis. Journal of International Business Studies, 39, 652-669. https://doi.org/10.1057/palgrave.jibs.8400371

[42] Meyer, K.E., Estrin, S., Bhaumik, S.K. and Peng, M.W. (2009) Institutions, Resources, and Entry Strategies in Emerging Economies. Strategic Management Journal, 30, 61-80. https://doi.org/10.1002/smj.720

[43] Click, R. and Weiner, R. (2010) Resource Nationalism Meets the Market: Political Risk and the Value of Petroleum Reserves. Journal of International Business Studies, 41, 783-803. https://doi.org/10.1057/jibs.2009.90

[44] Vaaler, P.M. (2008) How Do MNCs Vote in Developing Country Elections? Academy of Management Journal, 51, 21-43. https://doi.org/10.5465/AMJ.2008.30679060

[45] Bengoa, M. and Sanchez-Robles, B. (2003) Foreign Direct Investment, Economic Freedom and Growth: New Evidence from Latin America. European Journal of Political Economy, 19, 529-545. https://doi.org/10.1016/S0176-2680(03)00011-9

[46] Harrigan, K.R. (1988) Joint Ventures and Competitive Advantage. Strategic Management Journal, 9, 141-158. https://doi.org/10.1002/smj.4250090205

[47] Yamakawa, Y., Peng, M.W. and Deeds, D.L. (2008) What Drives New Ventures to Internationalize from Emerging to Developed Economies? Entrepreneurship Theory and Practice, 32, 59-82. https://doi.org/10.1111/j.1540-6520.2007.00216.x

[48] Yang, X., Jiang, Y., Kang, R. and Ke, Y. (2009) A Comparative Analysis of the In- 
ternationalisation of Chinese and Japanese Firms. Asia Pacific Journal of Management, 26, 141-162. https://doi.org/10.1007/s10490-007-9065-0

[49] Morck, R., Yeung, B. and Zhao, M. (2008) Perspectives on China's Outward Foreign Direct Investment. Journal of International Business Studies, 39, 337-350. https://doi.org/10.1057/palgrave.jibs.8400366

[50] Deng, P. (2004) Outward Investment by Chinese MNCs: Motivations and Implications. Business Horizons, 47, 8-16. https://doi.org/10.1016/S0007-6813(04)00023-0

[51] Globeman, S. and Shapiro, D. (2009) Economic and Strategic Considerations Surrounding Chinese FDI in the United States. Asia Pacific Journal of Management, 26, 163-183. https://doi.org/10.1007/s10490-008-9112-5

[52] Child, J. and Rodrigues, S.B. (2005) The Internationalisation of Chinese Firms: A Case for Theoretical Extension? Management and Organisation Review, 1, 381-410. https://doi.org/10.1111/j.1740-8784.2005.0020a.X

[53] Butler, K.C. and Joaquin, D.C. (1998) A Note on Political Risk and the Required Return on Foreign Direct Investment. Journal of International Business Studies, 29, 599-607. https://doi.org/10.1057/palgrave.jibs.8490009

[54] Garcia-Canal, E. and Guillen, M.F. (2008) Risk and the Strategy for Foreign Location Choice in Regulated Industries. Strategic Management Journal, 29, 1097-1115. https://doi.org/10.1002/smj.692

[55] Pak, Y.S. and Park, Y.R. (2004) Global Ownership Strategy of Japanese Multinational Enterprises: A Test of Internalisation Theory. Management International Review, 44, 3-21.

[56] Henize, W.J. and Zelner, B.A. (2005) Legitimacy, Interest Group Pressures and Change in Emergent Institutions: The Case of Foreign Investors and Host Country Governments. Academy of Management Review, 30, 361-382. https://doi.org/10.5465/AMR.2005.16387892

[57] Jensen, N.M. (2006) Nation-States and the Multinational Corporation: A Political Economy of Foreign Direct Investment. Princeton University Press, Princeton.

[58] Khanna, T. and Palepu, K.G. (2006) Emerging Giants: Building World Class Companies in Developing Countries. Harvard Business Review, 84, 60-70.

[59] Ahmed, Z.U., Mohamad, O., Tan, B. and Johnson, I.P. (2002) International Risk Perception and Mode of Entry: A Case Study of Malaysian Multinational Firms. Journal of Business Research, 55, 805-813. https://doi.org/10.1016/S0148-2963(00)00220-4

[60] Malhotra, S., Zhu, P. and Locander, B. (2010) Corruption and Foreign Investments: A Comparison of U.S. and Chinese Firms. Thunderbird International Business Review, 52, 491-507. https://doi.org/10.1002/tie.20375

[61] Chou, K.H., Chen, C.H. and Mai, C.C. (2011) The Impact of Third-Country Effects and Economic Integration on China's Outward FDI. Economic Modelling, 28, 2154-2163. https://doi.org/10.1016/j.econmod.2011.05.012

[62] Gomes-Casseres, B. (1990) Firm Ownership Preferences and Host Government Restrictions: An Integrated Approach. Journal of International Business Studies, 21, 1-22. https://doi.org/10.1057/palgrave.jibs.8490324

[63] Luo, Y. and Peng, M.W. (1999) Learning to Compete in a Transition Economy: Experience, Environment, and Performance. Journal of International Business Studies, 30, 269-296. https://doi.org/10.1057/palgrave.jibs.8490070

[64] Meyer, K.E. and Jensen, C. (2005) Foreign Direct Investment and Government Pol- 
icy in Central and Eastern Europe. In: Grosse, R., Ed., International Business and Government Relations in the 21 st Century, Cambridge University Press, New York, 119-145. https://doi.org/10.1017/CBO9780511488597.006

[65] Boisot, M. and Meyer, M.W. (2008) Which Way through the Open Door? Reflections on the Internationalization of Chinese Firms. Management and Organization Review, 4, 349-365. https://doi.org/10.1111/j.1740-8784.2008.00116.x

[66] De Haan, J. and Strum, J.E. (2000) On the Relationship between Economic Freedom and Economic Growth. European Journal of Political Economy, 16, 215-241. https://doi.org/10.1016/S0176-2680(99)00065-8

[67] Gylfason, T. and Zoega, G. (2006) Natural Resources and Economic Growth: The Role of Investment. World Economy, 29, 1091-1115. https://doi.org/10.1111/j.1467-9701.2006.00807.x

[68] Mehlum, H., Moene, K. and Torvik, R. (2006) Institutions and the Resource Curse. Economic Journal, 116, 1-20. https://doi.org/10.1007/978-3-540-79247-5 13

[69] Lane, P.R. and Tornell, A. (1999) The Voracity Effect. American Economic Review, 89, 22-46. https://doi.org/10.1257/aer.89.1.22

[70] Chan, C.M., Isobe, T. and Makino, S. (2008) Which Country Matters? Institutional Development and Foreign Affiliate Performance. Strategic Management Journal, 29, 1179-1205. https://doi.org/10.1002/smj.705

[71] Heritage Foundation (2015) Index of Economic Freedom. The Heritage Foundation, Washington DC.

[72] Bhaumik, S.K. and Co, C.Y. (2011) China's Economic Cooperation Related Investment: An Investigation of Its Direction and Some Implications for Outward Investment. China Economic Review, 22, 75-87. https://doi.org/10.1016/j.chieco.2010.09.002

[73] Kolstad, I. and Wiig, A. (2011) Better the Devil You Know? Chinese Foreign Direct Investment in Africa. Journal of African Business, 12, 31-50. https://doi.org/10.1080/1536710X.2011.555259

[74] Sutherland, D. (2009) Do China's “National Team” Business Groups Undertake Strategic-Asset-Seeking OFDI? Chinese Management Studies, 3, 11-24.

https://doi.org/10.1108/17506140910946115

[75] Hsiao, C. (2003) Analysis of Panel Data. 2nd Edition, Cambridge University Press, New York. https://doi.org/10.1017/CBO9780511754203

[76] Churchill, G.A. (1991) Marketing Research: Methodological Foundation. 5th Edition, The Dryden Press, Chicago.

[77] Bowerman, B., O’Connel, R. and Koehler, A. (2005) Forecasting, Time Series, and Regression. Thomas Brooks, Cole.

[78] Mathews, J.A. (2006) Dragon Multinationals: New Players in 21st Century Globalization. Asia Pacific Journal of Management, 23, 5-27. https://doi.org/10.1007/s10490-006-6113-0

[79] Peng, M.W. (2013) Global Strategy. 3rd Edition, South Western College Publishing.

[80] Peng, M.W. (2003) Institutional Transition and Strategic Choices. Academy of Management Review, 28, 275-296. 